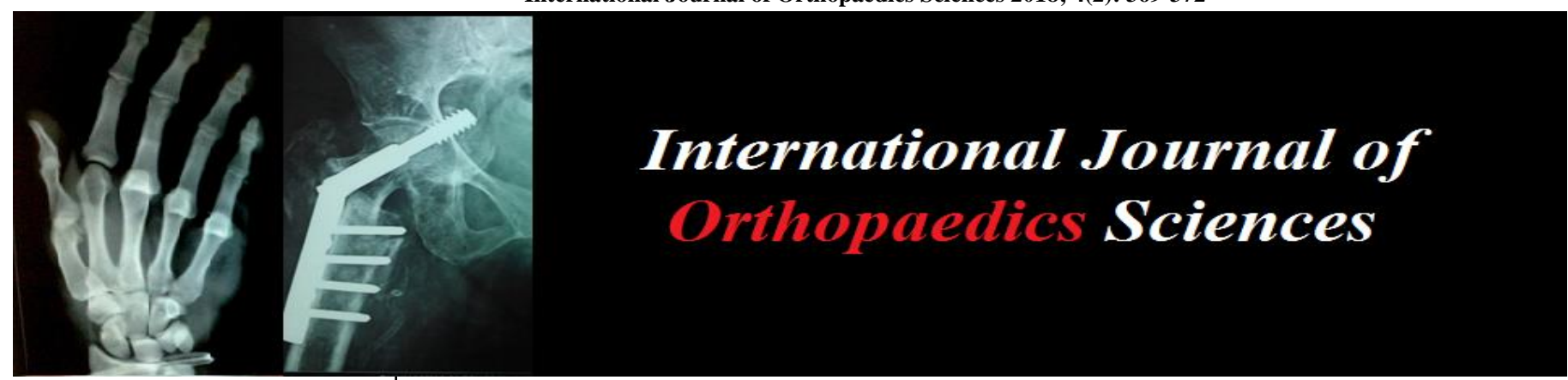

ISSN: $2395-1958$

IJOS 2018; 4(2): 369-372

(C) 2018 IJOS

www.orthopaper.com

Received: 21-02-2018

Accepted: 24-03-2018

Dr. Wasim Ahmed

Assistant Professor, department of Orthopaedics, IGIMS, Patna,

Bihar, India

Indrajeet Kumar

Associate Professor, department of Orthopaedics, IGIMS, Patna, Bihar, India

Dr. Santosh Kumar

Professor and Head, department of Orthopaedics, IGIMS, Patna, Bihar, India
Correspondence

Indrajeet Kumar

Associate Professor, department of Orthopaedics, IGIMS, Patna,

Bihar, India

\section{Interlocking nail for management of distal tibia fracture: our experience at tertiary center of Bihar}

\author{
Dr. Wasim Ahmed, Indrajeet Kumar and Dr. Santosh Kumar
}

DOI: https://doi.org/10.22271/ortho.2018.v4.i2f.58

\section{Abstract}

Introduction: Tibia is the most commonly fractured bone amongst all long bones of the body due to its position and lack of soft tissue protection. Treating tibia distal $1 / 3$ rd fracture is still a greater challenge because Most of the distal third tibia is subcutaneous and has precarious blood supply. Fractures of the distal third tibia have comminution at the fracture site and have associated significant soft tissue injury. Generally, associated with ecchymosis, blebs, swellings, wounds, etc. All these factors contribute to delayed union, non-union, and malunion. The present study is about the ability to maintain a mechanically stable reduction in the distal third tibia with intramedullary nail, when lower $4 \mathrm{~cm}$ of tibia not fractured. If associated with fibula fracture (in lower $10 \mathrm{~cm}$ ), it fixed to give stability to syndesmosis and stability to same-level tibia fracture.

Materials and methods: all patients of distal tibia fracture fulfilling the inclusion criteria from July 2011 to July 2017, were operated and followed up at every 4 weeks, till sign of union seen.

Results: 72 patients (male 40, female 32) with Mean age of was 35.2 years (20-50 yrs), Fracture union was seen radiologically within 12 to 20 weeks, depending on fracture geometry.

Conclusion: We found that results of fractures of distal third tibia not extending into lower $4 \mathrm{~cm}$ of tibia treated with interlock nailing were found satisfactory. Careful planning and placement of nail at the center of a wide metaphysis in the anteroposterior and lateral is necessary to avoid varus, valgus, and antero-posterior tilt. Polar screw or temporary K-wire during surgery was found to be helpful. Same-level fibula fracture fixation with a plate or $\mathrm{k}$-wire is effective for stability of reduction.

Keywords: Fracture distal third tibia, tnterlock tibia nailing, fracture fibula, plate, k-wire

\section{Introduction}

Tibia is the most commonly fractured bone amongst all long bones of the body due to its position and lack of soft tissue protection ${ }^{[1]}$. Treating tibia distal $1 / 3$ rd fracture is still a greater challenge ${ }^{[1]}$. Fracture of distal shaft without involving articular surface are of common occurrence but the management of these unstable extraarticular distal tibia fractures remains challenging. The mechanism of injury and the prognosis of these fractures are different from pillon fractures, but their proximity to the ankle makes the surgical treatment more complicated than the treatment of tibial midshaft fractures. A variety of treatment methods have been suggested for these injuries, including non-operative treatment, external fixation, intramedullary nailing and plate fixation ${ }^{[2]}$. However, each of these treatment options is associated with certain challenges. Non operative treatment may be complicated by loss of reduction and subsequent malunion. Similarly, external fixation of distal tibia fractures may result in insufficient reduction, malunion, and pin tract infection. Intramedullary nailing is indicated for the majority of closed lower third tibia and middle and lower third junction fractures of the tibia ${ }^{[3]}$ as well as for open fractures with adequate soft tissue cover when fracture is not extending into the lower $4 \mathrm{~cm}$ of tibia from the ankle joint ${ }^{[4]}$.

\section{Material and Methods}

All patients of fracture distal 1/3 tibia were enrolled from July 2011 to July 2017 in the study. The inclusion and exclusion criteria were as mentioned below. 


\section{Inclusion Criteria}

All extra articular closed fractures of distal 1/3

Patients of age $20-50$ years

Fresh fractures

Giving consent of surgery

\section{Exclusion Criteria}

Fracture of middle $1 / 3$ and proximal $1 / 3$ region of tibia

Patients treated conservatively or any other method for other medical reasons.

Open fractures.

Pathological fractures.

Patients who were lost to follow up or died before the fracture union.

Patient with nerve injury.

Not giving consent

The patients were admitted in emergency. The history was taken followed by general and local examination was done. Neurovascular status was noted. $X$ rays and routine investigation were done. The fracture was temporarily immobilized with a above knee slab. Pre-operative planning were done.After pre-anaesthetic check-up closed reduction and internal fixation done with interlocked nail (fig 1 and 2). Patients were discharged after stitch removal and followed up at every 4 week till radiological union was seen. At every follow up clinical examination was done to assess status of the surgical wound, pain, tenderness, range of motion of knee and ankle, fracture stability and clinical union.

\section{Operative Technique}

Intramedullary Nailing Surgery was done under spinal anesthesia under $\mathrm{C}$-arm control on radiolucent fracture table. Routine antiseptic scrubbing with povidone iodine scrub was done followed by painting with povidone iodine and draping of the operative area was done. Fractures are reduced by closed methods of gentle traction and external manipulation and guide wire passed and fixed in a central position ${ }^{(5)}$ in both AP and lateral view and reamed intramedullary nailing done. In treating distal third fractures, it is better to use temporary polar screw or thick K-wire, so that guide wire, reamer, and subsequent intramedullary nail remain in the center (as there is widening of medullary canal at the diaphysio-metaphyseal junction) so that varus/valgus or anterior posterior angulation can be avoided ${ }^{(6)}$. Special care is given for fixation of fibula with semi tubular plate or k-wire (Fig3, 4, 5, 6). Nail should be inseted up to the subchondral level at the ankle plafond ${ }^{[7]}$. We preferably lock three sites Two medial to lateral and one anteroposterior, if possible or at least two bolts one medial to lateral and one anteroposterior. Postoperatively, limb elevation and was given, as well as third-generation cephalosporin and amino glycosides were given intravenously for 5 days and oral antibiotics continued till $10^{\text {th }}$ postoperative day. Stitches were removed on $11^{\text {th }}$ post-operative day. Check $\mathrm{X}$-rays were taken.

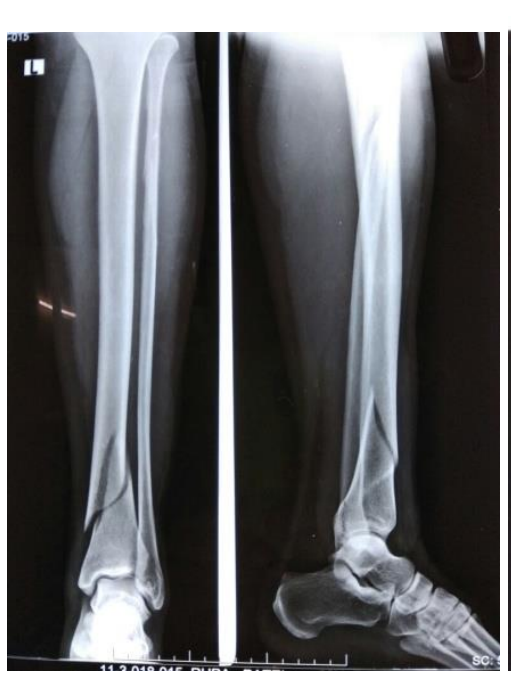

Fig 1

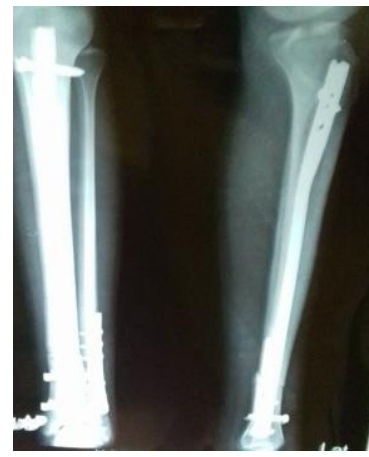

Fig 3

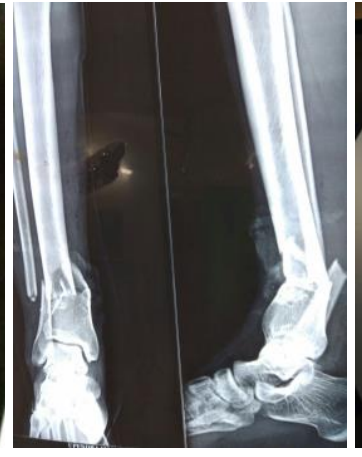

Fig 4

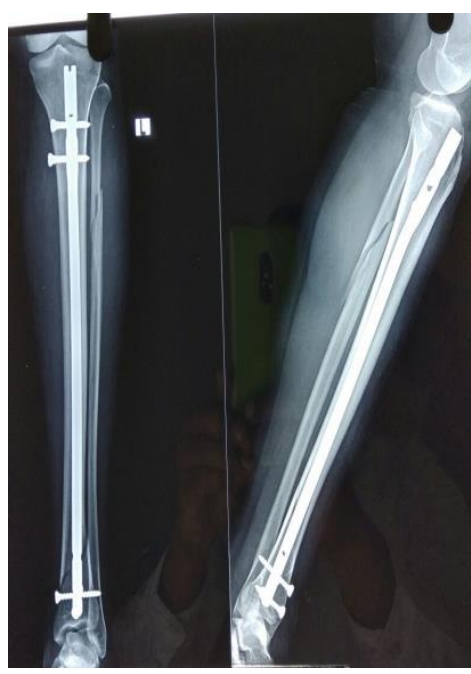

Fig 2

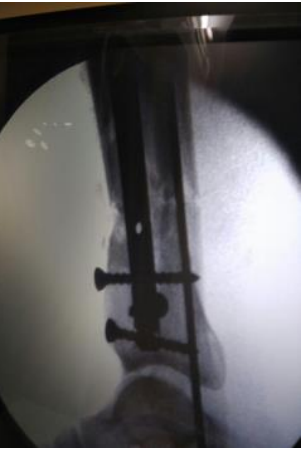

Fig 5

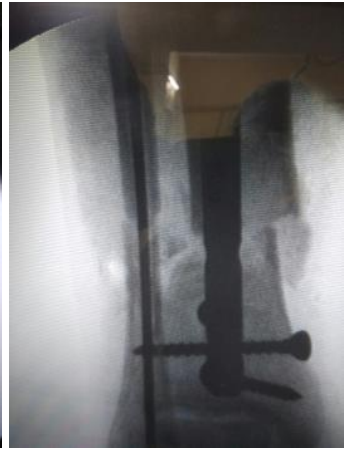

Fig 6

\section{Results}

There were total 72 patients [male $40(55.55 \%)$, female $32(44.44 \%)]$ treated with closed intramedullary locking nail. The mean age of patients were 35.2 yrs (age 20-50 years). Road traffic accident was major mode of injury followed by fall from height. The mean time of radiological union was 16.8 weeks ranging from 14 to 20 weeks. 72cases; of which, $52(72.22 \%)$ patients had no other fixation besides tibia nail. Mean operation time was 84 minutes (75-90 minutes). In 20 patients $(27.77 \%)$, CRIF and nailing with additional fibula 
fixation (with $\mathrm{k}$ wire or semi tubular plate) was done (Figs 3, $4,5,6)$.Complications of infections were found in eight patients. Superficial infection (6 cases, 8.33\%) were treated with dressing and broad-spectrum antibiotics, and deep infection ( 2 case, $2.77 \%$ ) needed implant removal and debridement after fracture union. Union of fracture was evident in both cases. In our study, we did stabilization of fibula fracture in $20(27.22 \%)$ out of total 72 patients. Five patients $(6.94 \%)$ had malunion at final outcome. Radiological and clinical union was evident in 70(97.22\%) patients with average duration of 16.8 weeks (14-20weeks). Two patients $(2.77 \%)$ had gone into non-union for which bone grafting was done.

Table 1: Demographic data

\begin{tabular}{|c|c|c|c|c|c|}
\hline & Swyang et al. ${ }^{[8]}$ & Mugundhan sengodan [9] & SatishR gawali et al. ${ }^{[11]}$ & Our study \\
\hline 1 & No of Patients & 13 & 20 & 60 & 72 \\
\hline 2 & M:F & $8: 5$ & $16: 4$ & $40: 20$ & $40: 32$ \\
\hline 3 & Age & $48.2+19$ & 35 & 35 & $35.2 \mathrm{yrs}$ \\
\hline 4 & Union Time (Week) & $22.6+4.3$ & 11.5 & 18 & 16.8 \\
\hline 5 & No of malunions & 03 & ---- & 03 & $5(6.94 \%)$ \\
\hline
\end{tabular}

Table 2: Mean peri-operative time duration

\begin{tabular}{|c|c|c|c|}
\hline Parameters & J J guo et al. $^{[\mathbf{1 0}]}$ & Satish R Gawati et al. ${ }^{[11]}$ & Our study \\
\hline Mean operating time (in minutes) & 81.23 & 89 & 84 \\
\hline Mean time to union (in weeks) & 17.7 & 18 & 16.8 \\
\hline Patients with wound problems (\%) & $3(6.8)$ & $4(6.6)$ & $8(11.11 \%)$ \\
\hline
\end{tabular}

Table 3: Final Outcome

\begin{tabular}{|c|c|c|c|c|c|c|}
\hline $\begin{array}{l}\text { S. } \\
\text { No }\end{array}$ & Study & Type & $\begin{array}{c}\text { No of } \\
\text { patients }\end{array}$ & Union (weeks) & Outcome & Complication \\
\hline 1 & Nork et al. ${ }^{[13]}$ & Prospective & 36 & $23.5 \mathrm{wks}$ & $92.0 \%$ & $\begin{array}{l}\text { 1- deep infection } \\
\text { 1-Iatrogenic\# }\end{array}$ \\
\hline 2 & $\begin{array}{l}\text { Dogra } \\
\text { et al. }{ }^{[12]}\end{array}$ & $\begin{array}{c}\text { Retrospective } 15 \\
\text { (fibula fixation not } \\
\text { done) } \\
\end{array}$ & 15 & $12-20 \mathrm{wks}$ & $\begin{array}{c}100 \% \\
3 \text { needed secondary procedure }\end{array}$ & \\
\hline 3 & $\begin{array}{l}\text { Satish R Gawali } \\
\text { el al }\end{array}$ & Prospective & 60 & $18(16-20)$ & $\begin{array}{l}02 \text { nail dynamization } \\
01 \text { exchange nail with bone }\end{array}$ & $\begin{array}{c}3 \text { Mal-union } \\
\text { 4 Superficial infection } \\
1 \text { deep Infection }\end{array}$ \\
\hline 4 & Our study & Prospective & 72 & $16.8(14.20 \mathrm{wks})$ & $97.22 \%$ union & $\begin{array}{c}6(8.33 \%) \text { Superficial infection } \\
2(2.77 \%) \text { deep infection } \\
5(6.94 \%) \text { Malunion } \\
2(2.77 \%) \text { nonunion need bone graft } \\
1(1.38 \%) \text { refracture due to re- trauma }\end{array}$ \\
\hline
\end{tabular}

\section{Discussion}

Distal metaphyseal fractures are challenging fractures to treat given the number of complications arising out of various surgical modalities of treatment. These fractures are most often high energy fractures resulting from axial and rotational force on distal tibia ${ }^{[14-17]}$. There are multiple studies in the literature comparing various modalities of treatment for distal tibial fractures. The various treatment options include plating, Nailing, AO external fixation, Ilizarov fixation to conservative treatment. Nonoperative treatment is also used in case of stable fractures with severe co morbidities but complications like delayed union, malunion and joints stiffness are very common ${ }^{[18,19]}$. Treating tibial distal third fractures associated with fibular fracture at the same level becomes even more difficult. This fracture pattern reflects a high-energy trauma causing significant soft tissue injury and gross comminution. Another clinical concern was in the distal $1 / 3$ rd tibia, the medullary canal is wide and in comparison, the diameter of the nail is less, So it reduces mechanical stability in lateral to medial plane and sometimes it calls for use of polar screw. When the fibula is fractured within $10 \mathrm{~cm}$ of the ankle joint, the ankle syndesmotic stability is jeopardized and needs stable fixation. The ability to maintain a mechanically stable reduction with intramedullary nail becomes more difficult when fracture extends distally and when there is metaphyseal comminution. Modern tibial nail designs have interlocking holes that enable distal placement of screw in close proximity to the tip of the nail, but these screws have less purchase in metaphyseal bone; there is increased stress on the screw to maintain fracture alignment as compared to locking screws in diaphysis and diaphysiometaphyseal junction ${ }^{[18]}$. With regard to complications in particular skin problems, infections are very less as compared to locking plate fixation. Dogra et al.. ${ }^{[12]}$ reported that in 3 patients of the 15 of their series presented angle in varus or valgus $>5^{\circ}$,without fibular fixation. Schmidt et al.. [5] reported that fibular fixation must be performed before fixing tibia with intramedullary nail when there is a major fibular deviation, because this helps on restoring the alignment of the limb or when there is gross tibial comminution. In the Dogra et al. study, ${ }^{[12]}$ three (20\%) patients had varus/valgus angulation $>5^{\circ}$ as they had not fixed the lower third fibula fracture. This mal-union is $20 \%$, which is significantly more than our series $(6.94 \%)$.

\section{Conclusion}

We concluded that fracture of distal third tibia not extending into the lower $4 \mathrm{~cm}$ of tibia treated with interlock nailing was satisfactory. Same level fibula fracture fixation with Semi tubular Plate or K-wire is effective for stability of reduction.

\section{References}

1. Paige W. Fracture of lower extremity: tibia pilon fracture. In: Terry C. James B (eds) Campbell's operative orthopaedics, eleventh edition, Philadelphia: Mosby Elsevier. 2010, 3118-19 
2. Boris Zelle A, Mohit Bhandari, Michael Espiritu. Treatment of Distal Tibia Fractures without Articular Involvement: A Systematic Review of 1125 Fractures. J Orthop Trauma. 2006; 20:76-79.

3. Robinson CM, McLauchlan GJ, McLean IP, CourtBrown CM. Distal metaphyseal fractures of the tibia with minimal involvement of the ankle: classification and treatment by locked intramedullary nailing. J Bone Joint Surg Br 1995; 77(5):781-787.

4. Gorczyca JT, McKale J, Pugh K, Pienkowski D. Modified tibial nails for treating distal tibia fractures. $\mathbf{J}$ Orthop Trauma. 2002; 16(1):18-22.

5. Schmidt AH, Finkemeier CG, Tornetta PIII. Treatment of closed tibial fractures. Instructional Course Lectures, the American Academy of Orthopaedic Surgeons. J Bone Joint Surg Am. 2003; 85:352-368.

6. Schmitt AK, Nork SE, Winquist RA. Intramedullary nailing of distal metaphyseal tibial fractures. Read at the Annual Meeting of the Orthopaedic Trauma Association, San Antino, TX; 2000, 13.

7. Tyllianakis $\mathrm{M}$, Megas $\mathrm{P}$, Giannikas D, Lambiris E. Interlocking intramedullary nailing in distal tibial fractures. Orthopedics. 2000; 23(8):805-808

8. Yang SW, Tzeng HM, Chou YJ, Teng HP, Liu HH, Wong CY. Treatment of distal tibial metaphyseal fractures: plating versus shortened intramedullary nailing. Injury 2006; 37(6):531-535.

9. Moongilpatti Sengodan M, Vaidyanathan S, Karunanandaganapathy S, Subbiah Subramanian S, Rajamani SG. Distal tibial metaphyseal fractures: does blocking screw extend the indication of intramedullary nailing? ISRN Orthop 2014, 542-623.

10. Guo JJ, Tang N, Yang HL, Tang TS. A prospective, randomised trial comparing closed intramedullary nailing with percutaneous plating in the treatment of distal metaphyseal fractures of the tibia. J Bone Joint SurgBr 2010; 92(7):984-988. Erratum in: J Bone Joint SurgBr 2010; 92(12):1717.

11. Satish R Gawali, Shashikant B Kukale, Pramod V Nirvane, Raman O Toshniwal. Management of Fractures of Distal third Tibia by Interlock Nailing The Journal of Foot and Ankle Surgery (Asia-Pacific). 2016; 3(1):15-22

12. Dogra AS, Ruiz AL, Thompson NS, Nolan PC. Diametaphyseal distal tibial fractures - treatment with a shortened intramedullary nail: a review of 15 cases. Injury. 2000; 31(10):799-804.

13. Nork SE, Schwartz AK, Agel J, Holt SK, Schrick JL, Winquist RA. Intramedullary nailing of distal metaphyseal tibial fractures. J Bone Joint Surg Am. 2005; 87(6):1213-1221.

14. Newman SD, Mauffey CP, Krikler S. Distal metaphyseal tibial fractures. Injury. 2011; 42:975-84.

15. Richard RD, Kubiak E, Horwirtz DS. Techniques of surgical treatment of distal tibial fractures. Orthop Clin North Am. 2014; 45:295-312.

16. Bedi A, Le TT, Karunakar MA. Surgical treatment of nonarticular distal tibia fractures. J Am Acad Orthop Surg. 2006; 14:406-16.

17. Vallier HA, Cureton BA, Patterson BM. Factors influencing functional outcomes after distal tibia shaft fractures. J Orthop Trauma. 2012; 26:178-83.

18. Othman M, Strzelczyk P. Results of conservative treatment of pilon" fractures. Ortop Traumatol Rehabil. 2003; 5:787-94.

19. Sarmiento A, Latta LL. 450 closed fractures of the distal third of the tibia treated with a functional brace. Clin Orthop Relat Res. 2004; 428:261-71. 